\title{
Hubungan Peran Ayah dan Dukungan Sosial Teman Sebaya dengan Determinasi Diri Pada Remaja Pecandu Narkoba di Klinik Pemulihan Adiksi Medan Plus
}

\section{The Relationship of Father's Role and Peer Social Support with Self-Determination in Adolescent Drug Addicts in Medan Plus Addiction Recovery Clinic}

\author{
Evicenna Yuris, Nefi Darmayanti \& Irna Minauli \\ Program Studi Magister Psikologi, Program Pascasarjana,Universitas Medan Area
}

\begin{abstract}
Abstrak
Penelitian ini bertujuan untuk mengetahui hubungan peran ayah dengan determinasi diri, hubungan dukungan sosial teman sebaya dengan determinasi diri, dan hubungan antara peran ayah dan dukungan sosial teman sebaya dengan determinasi diri pada remaja pecandu narkoba. Populasi dalam penelitian ini adalah remaja pecandu narkoba di Klinik Pemulihan Adiksi Medan Plus. Sampel berjumlah 54 orang remaja yang diambil dengan teknik purposive sampling. Instrumen yang digunakan adalah skala determinasi diri, skala peran ayah dan skala dukungan sosial teman sebaya. Hasil analisis regresi berganda menunjukkan nilai Freg sebesar 11,071 dengan $p=0,000$ $(p<0,005)$ hal tersebut menunjukkan bahwa terdapat hubungan yang signifikan antara determinasi diri dan peran ayah dengan dukungan sosial teman sebaya. Secara parsial, terdapat hubungan antara determinasi diri dengan peran ayah rxy $=0,543$ dengan $p<0,01$, serta terdapat hubungan antara dukungan sosial teman sebaya dengan determinasi diri rxy $=0,384$ dengan $p<0,01$. Nilai R2 sebesar 0,303 artinya peran ayah dan dukungan sosial teman sebaya secara bersama-sama memberi sumbangan efektif sebesar 30,3\% terhadap determinasi diri.

Kata Kunci: Peran Ayah, Dukungan Sosial Teman Sebaya, Determinasi Diri
\end{abstract}

\begin{abstract}
This study aims to determine the relationship of the role of fathers with self-determination, the relationship of peer social support with self-determination, and the relationship between the role of fathers and peer social support with self-determination in adolescent drug addicts. The population in this study were adolescent drug addicts in Medan Plus Addiction Recovery Clinic. A sample of 54 teenagers were taken by purposive sampling technique. The instrument used was a scale of self-determination, the scale of the role of fathers and the scale of peer social support. The results of multiple regression analysis showed a Freg value of 11,071 with $p=0,000(p<0,005)$, which indicated that there was a significant relationship between self-determination and the role of fathers with peer social support. Partially, there is a relationship between self-determination with the role of father $r x y=0.543$ with $p<0.01$, and there is a relationship between social support of peers with self-determination $r x y=0.384$ with $p<0.01$. R2 value of 0.303 means the role of fathers and social support of peers together make an effective contribution of $30.3 \%$ of self-determination.

Keywords: Father's Role, Peer Social Support, Self Determination
\end{abstract}

How to Cite: Yuris, E., Nefi, D., Irna, M. (2019). Hubungan Peran Ayah dan Dukungan Sosial Teman Sebaya dengan Determinasi Diri Pada Remaja Pecandu Narkoba di Klinik Pemulihan Adiksi Medan Plus. Tabularasa: Jurnal Ilmiah Magister Psikologi, 1(2) 2019: 138-153

*E-mail: evicenna83@gmail.com

ISSN 2550-1305 (Online)

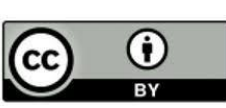




\section{PENDAHULUAN}

Manusia merupakan mahluk yang memiliki berbagai keistimewaan yang tidak dimiliki oleh mahluk ciptaan Tuhan yang lain. Dalam menjalani hidup dan kehidupannya, manusia selalu berupaya untuk mencapai keadaan yang menurutnya baik. Semakin tumbuh dan berkembangnya manusia maka semakin beragam pula dorongan yang ada dalam diri untuk memenuhi kebutuhannya. Cara yang dilakukan untuk memenuhi kebutuhan itu pun juga beragam (Ahmad dalam Mahaldi, 2007).

Charm dkk (dalam Schunk dkk, 2012) menjelaskan bahwa dorongan yang ada dalam diri manusia disebut motivasi, dan motivasi membentuk suatu kebutuhan mandiri dalam melakukan berbagai aktivitas karena mereka menginginkannya.

Terkait hal tersebut motivasi dalam diri manusia menetapkan tujuan untuk diri dan mengarahkan perilaku manusia. Rotter dkk (dalam Schunk, 2012) memperjelas bahwa determinasi diri merupakan salah satu bagian dari motivasi instrinsik yang pada perspektifnya fokus pada kontrol internal. Dalam pandangan ini manusia percaya bahwa mereka melakukan sesuatu atas dasar kemauan mereka sendiri.

Deci \& Ryan (dalam Schunk, 2012) mendefinisikan determinasi diri adalah suatu proses memanfaatkan kehendak yang dimiliki oleh diri, kehendak dalam hal ini adalah suatu kapasitas manusia untuk memilih cara memuaskan kebutuhan-kebutuhannya.

Determinasi diri menuntut agar individu-individu mengetahui kemampuan bertindak atas dirinya dalam membuat pilihan dan menentukan cara-cara mememenuhi kebetuhannya. Kehendak dan determinasi diri saling berkaitan. Kebutuhan akan determinasi diri adalah individu percaya bahwa kemandirian yang dimiliki individu berkenaan dengan hal-hal yang akan mereka lakukan dan tentang tindakan yang akan mereka ambil atas dasar kemauan mereka sendiri.

Berdasarkan paparan tersebut dapatlah dikatakan bahwa determinasi diri merupakan kemampuan diri dalam mengidentifikasi dan mencapai tujuan berdasarkan pengetahuan dan penilaian individu terhadap dirinya sendiri dan determinasi diri fokus pada kontrol diri. Determinasi diri menjadi penting karena adanya proses pengembangan diri di dalam diri individu. Pengembangan diri ini akan memberikan tujuan hidup yang bermakna bagi seseorang, dan melalui interaksi dengan lingkungan individu mendapatkan masukan-masukan dari individu lain sehingga akan selalu termotivasi tinggi dalam meraih tujuannya.

Remaja adalah usia yang sangat penting dalam menentukan identitas diri dan bagaimana mereka memutuskan keinginan dari hal-hal baru yang didapat dengan apa yang menjadi kebutuhan mereka. Pada masa perkembangan ini remaja sangat rentan dalam kaitannya untuk memtuskan banyak pilihan dengan rasa ingin tahu mereka. Memiliki detereminasi diri yang tinggi sangat penting dimiliki seorang remaja yang sedang mengalami banyak gejolak dalam pemikiran-pemikirannya. Determinasi diri merupakan bagian dari perkembangan sumber daya manusia yang terfokus pada perkembangan kepribadian dan regulasi diri atau kemampuan untuk mengontrol perilaku sendiri.

Menurut Plato and Rouseau (dalam Santrock, 2007) remaja tahap 4 adalah berusia 15-20 tahun dapat dikatakan individu mulai menjadi matang secara emosional, selama 
masa ini sifat mementingkan diri sendiri diganti dengan minat pada orang lain, nilai dan moral juga tampil pada perkembangan masa ini.

Remaja masa kini menghadapi tuntutan dan harapan, juga bahaya dan godaan yang tampaknya lebih banyak dan kompleks dibanding remaja generasi yang lalu. Dukungan keluarga dan sosial yang tidak efektif membuat remaja tidak memperoleh cukup kesempatan dan dukungan untuk menjadi orang dewasa yang kompeten. Dari beberapa media jurnalistik seperti televisi, surat kabar, dan media online sudah banyak memberitakan kondisi kebanyakan remaja Indonesia saat ini yang mengalami kemunduran secara moral, budi pekerti, dan kematangan emosi. Hal ini dapat dilihat dari kasus pergaulan bebas yang semakin meningkat, gaya hidup yang semakin kebaratbaratan, narkoba, dan kasus-kasus depresif seperti percobaan bunuh diri.

Badan Kependudukan dan Keluarga Berencana (BKKBN, 2011) juga menambahkan data remaja Indonesia mengalami kemunduran secara moral. Beberapa data mengenai perilaku maladaptif remaja menunjukkan dari 2,4 juta perempuan yang melakukan aborsi, 700-800 ribu adalah remaja. Dari 1283 kasus HIV/AIDS, diperkirakan 52.000 terinfeksi dimana $70 \%$ adalah remaja.Selain masa remaja identik dengan masa yang rawan dengan bahaya dan godaan, masa remaja juga merupakan masa untuk mengeksplorasi sebanyak mungkin potensi positif mereka. Pada masa ini remaja dituntut untuk mengembangkan diri sebaik mungkin sebagai bekal mereka memasuki masa dewasa. (Data diperoleh dari Klinik Pemulihan Adiksi Medan Plus).

Di kalangan remaja, sangat banyak kasus tentang penyalahgunaan narkoba. Berdasarkan survey BNN tahun 2005 terhadap 13.710 responden kalangan pelajar dan mahasiswa menunjukkan penyalahgunaan narkoba usia termuda 7 tahun dan rata-rata pada usia 10 tahun. Survey dari BNN ini memperkuat hasil Prof. Dr. Dadang Hawari pada tahun 1991 yang menyatakan bahwa 97\% pemakai narkoba yang ada selama tahun 2005, 28\% pelakunya adalah remaja usia 17-24 tahun. (Data diperoleh dari Klinik Pemulihan Adiksi Narkoba Medan Plus).

Undang-undang nomor 35 tahun 2009 tentang narkotika pasal 1 tentang pengertian pecandu adalah orang yang menggunakan narkotika dan dalam keadaan ketergantungan pada narkotika baik secara fisik maupun psikis.

Terkait dengan determinasi diri, remaja pecandu narkoba dapatlah dikatakan memiliki determinasi diri rendah karena memilih untuk menggunakan narkoba dapat diartikan tidak adanya kontrol diri dalam memilih tujuan hidup.

Meski tidak banyak ilmuwan yang membicarakan bagaimana pentingnya kehadiran seorang ayah dalam perkembangan remaja, tetapi suatu bukti yang sederhana bahwa ketidakhadiran ayah dalam diri remaja berpengaruh kuat terhadap perkembangan mental intelektual anak. Terbukti dari penelitian yang dilakukan Misched (dalam Dagun, 2002) yang menunjukkan hasil ternyata karena ketidakhadiran ayah remaja menjadi lamban menanggapi kehendak, keinginan, dan kebutuhannya.

Pemaparan tersebut mematahkan paradigma banyak orang, bahwa tugas mendidik anak adalah tanggungjawab atau tugas para istri atau ibu. Tugas ayah atau suami adalah bekerja. Jadilah para ayah sibuk diluar rumah, tanpa mempedulikan proses pendidikan 
dan tumbuh kembang anak-anak mereka. Apabila terjadi sesuatu hal yang buruk pada sang buah hati, maka ibu adalah pihak pertama yang harus bertanggungjawab karena dianggap tidak mampu mengurus rumah tangga dan anak-anak. Semakin parahnya tingkat kenakalan remaja, menurut para ahli disebabkan oleh kurangnya figur ayah dalam kehidupan mereka. Boleh jadi secara karier, para ayah berhasil mencapai puncak prestasi. Namun apa arti semua itu jika dibalik kesuksesan tersebut mereka gagal dalam mendidik keluarga (Rianti, 2013).

Menurut Syamsi (dalam Mahaldi, 2015) anak patut diberi kepercayaan dengan diberikan kebebasan. Tidak dengan terus menerus mengawasi dan membuntuti sang anak. Biarkan sang anak pergi sendirian jika sudah mencapai usia tertentu dan berikan kebebasan. Namun berikan pengertian padanya bahwa kebebasannya adalah tanggungjawabnya. Saat sesuatu dilakukan, tentu ada kewajiban yang harus di kerjakan setelahnya, sehingga belajar dan bermain adalah hal yang menyenangkan baginya, bukan sebaliknya membuat anak menjadi depresi.

Dari data yang ada diklinik pemulihan adiksi Medan Plus bahwasanya mereka yang beresiko terjerumus dalam masalah penyalahgunaan narkoba adalah anak yang terlahir dari keluarga broken home, atau keluarga bermasalah. Konselor juga menyatakan bahwa yang paling banyak datang untuk berkonsultasi adalah para ibu-ibu dan yang mengantarkan remaja untuk rehabilitasi adalah para ibu. Pada kesempatan kunjungan keluarga juga hanya sosok ibu yang paling sering hadir menjenguk para remaja yang sedang menjalani rehabilitasi di Klinik Pemulihan Adiksi Medan Plus, dan beberapa remaja pecandu tersebut awal menggunakan narkoba karena ajakan temannya.

Dalam konteks determinasi diri individu secara alami akan mengatur diri dan bertindak sesuai nilai-nilai dan keinginan mereka, lingkungan sosial dapat dengan mudah mengurangi fungsi kemandirian seseorang. Menurut Gronick (dalam Amie, 2013) ketika seorang remaja diasuh secara tidak konsisten dan dikontrol secara berlebihan, pengaturan determinasi diri mereka akan terhambat. Terkait dengan hal tersebut ada peran serta dan dukungan sosial dari lingkungan sosial yang juga sangat mempengaruhi determinasi diri remaja yaitu kehadiran teman sebaya.

Meskipun remaja masih bergantung pada orangtuanya, namun intensitas ketergantungan tersebut telah berkurang dan remaja mulai mendekatkan diri pada teman-teman yang memiliki rentang usia yang sama dengan dirinya. Remaja mulai belajar mengekspresikan perasaan-perasaan dengan cara yang lebih matang dan berusaha memperoleh kebebasan emosional dengan cara menggabungkan diri dengan teman sebayanya. Hal ini dilakukan remaja dengan tujuan untuk mendapatkan pengakuan dan dukungan dari kelompok teman sebaya. Melalui berkumpul dengan teman sebaya yang memiliki kesamaan dalam berbagai hal tertentu, remaja dapat mengubah kebiasaan hidupnya dan dapat mencoba berbagai hal baru serta saling mendukung satu sama lain (Cairn, dalam Amie, 2013)

Beminof (dalam Amie, 2013) menegaskan bahwa kelompok teman sebaya merupakan dunia nyata remaja yang menyiapkan tempat remaja menguji dirinya dengan orang lain. Cairns \& Neckerman (1998) menambahkan keberadaan remaja dalam kehidupan remaja merupakan keharusan, untuk itu seorang remaja harus mendapatkan 
penerimaan yang baik untuk memperoleh dukungan dari kelompok teman sebayanya, melalui berkumpul dengan teman sebaya yang memiliki kesamaan dalam berbagai hal tertentu, remaja dapat mencoba berbagai hal yang baru serta saling mendukung satu sama lain.

Dalam penelitian ini peneliti mengikutsertakan variabel lain yaitu dukungan sosial teman sebaya dalam membangun determinasi diri remaja, mengingat teman sebaya merupakan sumber referensi bagi remaja mengenai berbagai hal, juga dapat memberikan kesempatan bagi remaja untuk mengambil peran dan tanggungjawab yang baru melalui dukungan sosial, dimana dukungan sosial merupakan pendekatan motivasi dan kepribadian yang merupakan aspek yang penting bagi determinasi diri (Tarigan, 2018; Siregar, 2018; Nainggolan, et al., 2017; Hamdani, et al., 2015; Zuraida, et al., 2015).

Dalam hal peran ayah dan dukungan sosial teman sebaya, Ladd \& Petit (dalam Santrock, 2007) mengungkapkan orangtua yang dalam hal ini peran ayah melatih anak dalam berhubungan dengan teman sebaya, orangtua merekomendasikan strategi mengatur kehidupan remaja dan kesempatan berinteraksi dengan teman sebaya. Carlson dkk (2005) menyatakan dalam penelitian yang dilakukannya menunjukan bahwa hubungan orangtua dan anaknya berfungsi sebagai dasar emosional untuk menjelajahi dan menikmati hubungan teman sebaya.

Tujuan penelitian dapat dikaitkan dengan usaha pemecahan masalah. Berdasarkan rumusan masalah penelitian yang ingin dijawab maka tujuan penelitian ini adalah: Untuk mengetahui hubungan antara determinasi diri remaja dengan peran ayah; Untuk mengetahui hubungan antara determinasi diri remaja dengan dukungan sosial teman sebaya; Untuk mengetahui hubungan antara peran ayah dan dukungan sosial teman sebaya dengan determinasi diri remaja.

Deci dkk (dalam Schunk, 2012) menyatakan determinasi diri adalah suatu proses memanfaatkan kehendak yang dimiliki oleh diri. Kehendak yang dimaksud adalah suatu kapasitas manusia untuk memilih cara memuaskan kebutuhan-kebutuhannya. Kehendak dan determinasi diri saling berkaitan, untuk memiliki determinasi diri individu-individu harus menentukan cara menindaklanjuti dan cara berinteraksi dengan lingkungan mereka.

Ryan dkk (dalam Nailul, 2015) menjelaskan bahwa determinasi diri adalah sebuah pendekatan motivasi dan kepribadian manusia yang menggunakan metode empiris tradisional dengan menggunakan teori organisme yang menyoroti pentingnya sumber daya manusia untuk pengembangan kepribadian dan perilaku regulasi diri, atau teori empiris yang berasal dari motivasi dan kepribadian manusia dalam konteks sosial yang membedakan motivasi dibagian yang otonom dan terkontrol. Secara sadar motivasi sangatlah dibutuhkan oleh setiap individu sebagai pengembangan kepribadian dan regulasi diri dalam interaksi sosial dilingkungan masyarakat. Determinasi diri fokus pada kontrol diri menentukan kehendak atau tujuan hidup sebagai pemenuhan kebutuhankebutuhan hidup.

Deci \& Ryan (dalam Schunk, 2012) merangkum sebuah penelitian yang mendukung determinasi diri. Dalam penelitian tersebut menunjukkan sebuah proses terjadinya 
determinasi diri yang mencakup pemberian penghargaan yang dikontrol oleh individu lain. Akhir dari hasil penelitian tersebut menunjukkan bahwa motivasi ekstrinsik menjadi bagian dari determinasi diri. Dalam penelitian ini ia mengembangkan sebuah subteori yang termasuk di dalam teori determinasi diri yang lebih besar, mereka melebelkan sebagai Teori Integrasi Organisme (Organismic Integration Theory) untuk menangani berbagai perilaku yang termotivasi secara ekstrinsik.

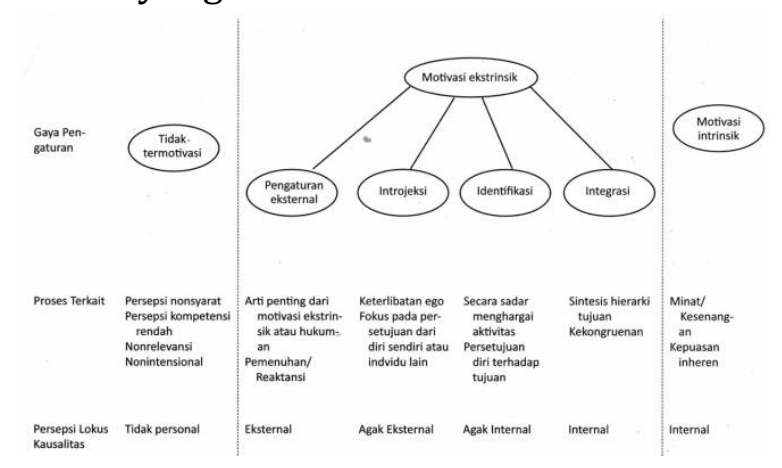

Seperti yang ditunjukkan dalam Gambar di atas, Deci dan Ryan (dalam Schunk, 2012) mengonsep motivasi sebagai proses terbentuknya determinasi diri, dimulai dari tidak termotivasi, lalu dengan motivasi ekstrinsik menumbuhkan motivasi instrinsik. Ini merupakan fokus dari Evaluasi Kognitif, dalam hal ini individu telah memilih aktivitas sebagai tujuan akhir dari kesenangannya. Dimulai dari perilaku yang tidak termotivasi, sepenuhnya termotivasi secara ekstrinsik kemudian dihayati dan selanjutnya terjadilah motivasi instrinsik dan merasakan determinasi diri.

Sisi paling kiri gambar menunjukan perilaku yang tidak termotivasi. Individu tidak merasa kompeten (keefektifan diri rendah, keyakinan kapasitas rendah), individu yang memiliki gaya pengaturan seperti ini tidak merasa bahwa tindakan mereka intensional (dilakukan berdasarkan niat atau keinginan) atau tidak merasa determinasi diri dalam tindakan mereka.

Deci \& Ryan (dalam Shunck, 2012) menjelaskan bagian tengah gambar ini menunjukan empat gaya motivasi atau gaya pengaturan diri ekstrinsik yang membuat individu termotivasi.

Level pertama disebut sebagai pengaturan eksternal. Dalam hal ini individu tidak termotivasi secara instrinsik dan tidak menunjukan minat yang tinggi. Kontrol bersifat eksternal dan tidak ada determinasi diri.

Level kedua disebut sebagai pengaturan introjeksi dalam hal ini sumber motivasi bersifat internal, namun tidak merasakan determinasi diri karena individu pada level ini dalam melakukan sesuatu hanya untuk menyenangkan individu lain.

Level ketiga disebut pengaturan identifikasi dalam hal ini individu melakukan aktivitas karena menyadari aktivitas tersebut dianggap penting bukan hanya untuk orang lain. Perilaku ini menggambarkan tujuan individu secara personal.

Level motivasi ekstrinsik terakhir adalah pengaturan integrasi yakni individu mengintegrasikan berbagai sumber informasi internal dan eksternal kedalam skema diri sendiri, menjalankan perilaku karena kepentingan bagi pemahaman tentang diri individu 
tersebut. Pada level ini menggambarkan bentuk determinasi diri dan otonomi. Pengaturan integrasi menyebabkan lebih banyak keterlibatan kognitif dan pembelajaran.

Pada bagian terakhir gambar motivasi instrinsik yang terjadi sebagai bentuk dari keputusan diri atas dasar kebutuhan individu. Individu bertindak dalam minat, kesenangan dan kepuasan sesuai dengan tujuan hidup yang ingin dicapai dan hal tersebut adalah determinasi diri.

Teori determinasi diri diperkenalkan lebih dari 20 tahun oleh dua Psikolog Deci \& Ryan (dalam Schunk, 2012) mereka mengusulkan tiga dimensi dalam determinasi diri: Kompetensi (competence). Kompetensi didefinisikan sebagai kebutuhan untuk mempengaruhi lingkungan yang terlihat dalam hasil penting dilingkungan, motivasi jenis apapun sekarang individu harus merasa kompeten dalam tugas tangan.Hal ini diterima secara luas bahwa tingkat yang lebih tinggi dari kompetensi adalah motivasi yang ada dalam determinasi diri. Dalam penelitian yang Deci \& Ryan menunjukan bahwa remaja dengan tingkat kompetensi yang lebih tinggi dianggap lebih aktif dalam kegiatan belajar dikelas. Kompetensi berfokus pada keinginan bertindak efektif dalam menghadapi lingkungan. Kompetensi menjadikan individu lebih siap dan berani untuk menghadapi tantangan dilingkungannya.

Kompetensi individu akan lebih terlihat dalam kegiatan yang mereka rasa berguna bagi mereka dan ini berhubungan dengan kelompok-kelompok sosial yang mereka nilai. Kompetensi adalah nutrisi yang melibatkan pemahaman bagaimana untuk mencapai hasil yang baik dari suatu tindakan yang diminta untuk dilakukan. Markland (dalam Nailul, 2015) mendefinisikan kompetensi sebagai kemampuan persepsi seseorang dalam negosiasi konteks sosial. Kompetensi memiliki dampak yang signifikan terhadap motivasi instrinsik hanya ketika dimediasi oleh determinasi diri, artinya ketika individu memiliki persepsi kompetensi yang tinggi, mereka merasa tidak memiliki otonomi, motivasi tidak mungkin untuk ditingkatkan. Dalam hal ini adaptasi yang didapat dari motivasi diri adalah hasil dari determinasi diri individu yang telah mampu mengontrol dirinya.

Winner (dalam Schunk, 2012) menambahkan kebutuhan untuk memiliki kompetensi serupa dengan kebutuhan memiliki interaksi sosial yang baik. Individuindividu perlu merasa dirinya kompeten dalam bertingkah laku dan dalam berinteraksi dengan individu lain.

Kemandirian atau Otonomi (autonomy). Otonomi diartikan sebagai rasa perasaan bebas dari tekanan dan memiliki kemungkinan untuk membuat pilihan diantara beberapa serangkaian tindakan, otonomi memiliki efek yang lebih kuat pada motivasi instrinsik dari pada kompetensi. Otonomi akan menjadikan individu lebih mandiri dan yakin terhadap prinsip dan pilihan yang telah ditetapkan. Dapat juga dijelaskan otonomi adalah mengatur diri sendiri.

Hagger dkk (dalam Santrock, 2007) ketika individu mengalami rasa otonomi rendah, tingkat kompetensi mereka menjadi sangat penting dalam kaitannya dengan motivasi instrinsik. Artinya ketika seseorang sedang dalam kesulitan berfikir tentang dirinya ada kompetensi yang diandalkannya dapat membantu mencapai satu tujuan. 
Keterkaitan atau keterhubungan (relatedness). Keterkaitan terdiri dari pengembangan percaya diri dan pemenuhan hubungan dengan oranglain.Individu telah mengembangkan hubungan yang aman dengan orang laindan mereka berada dalam lingkungan otonomi yang mendukung, dimana pengakuan perasaan, pilihan, dan kesempatan untuk arah diri yang dipromosikan.Keterkaitan dan keterhubungan dicontohkan oleh kondisi mencintai dan merawat oranglain, dimana cinta dan perawatan juga diterima oleh diri individu.

Fiest \& Fiest (2008) menambahkan bahwa kebutuhan adalah keterhubungan yaitu dorongan untuk menyatu dengan sebuah pribadi dengan pribadi lainnya.

Keterkaitan atau keterhubungan berfokus pada kecenderungan universal untuk berinteraksi, merasa terhubung, merasa terlibat, dan untuk merasakan kasih sayang dan kepedulian terhadap orang lain.

Dari beberapa penjelasan dimensi-dimensi di atas, dengan demikian konsep dimensi determinasi diri ini adalah kemandirian atau otonomi adalah bertindak atas kemauannya sendiri, individu merasa mandiri ketika membuat keputusan untuk dirinya tanpa tekanan dari luar, ketika seseorang terlibat dalam suatu kegiatan dikarenakan mereka tertarik dengan kegiatan tersebut, mereka akan melakukan aktivitas tersebut sepenuhnya karena keinginannya sendiri.

Begitu juga tugas kompetensi dalam diri adalah membuat individu tahu apa yang seharusnya dilakukan dan hal apa yang membuat mampu untuk mencapainya. Keterkaitan atau keterhubungan dalam hal ini menunjukan perasaan diri untuk terhubung dengan orang lain seperti menjadi bagian dari kelompok tertentu dan kelompok tersebutpun memiliki rasa peduli terhadap individu.

Ayah menurut Bloir (dalam Dagun, 2002) dapat berperan penting bagi perkembangan pribadi anak, baik sosial, emosional maupun intelektualnya. Pada diri anak akan tumbuh motivasi, kesadaran dirinya, dan identitas skill serta kekuatan/kemampuan-kemampuannya sehingga memberi peluang untuk sukses belajarnya, identitas gender yang sehat, perkembangan moral dengan nilainya dan sukses lebih primer dalam keluarga dan kerja/kariernya kelak. Terhadap semua itu pengaruh peran ayah yang paling kuat adalah terhadap kemandirian anak dan hubungan sosial yang harmonis.

Biller dkk (dalam Santrock, 2007) menyatakan bahwa peranan ayah telah mengalami perubahan-perubahan utama.Para ayah terutama bertanggung jawab memberi pelajaran moral. Ayah menyediakan petunjuk dan nilai, terutama melalui agama. Pembagian peran yang kaku antar Ayah dan Ibu tidak memadai dan bukan zamannya lagi. Baik ayah maupun ibu, semuanya menjalani peran-multi didalam keluarga.

Berdasarkan uraian diatas maka peran ayah adalah keterlibatan ayah akan mengembangkan kemampuan anak untuk berempati, bersikap penuh kasih sayang dan penuh perhatian, serta hubungan sosial yang lebih baik dalam mengembangkan pengendalian diri dan penyesuaian sosial, sering diidentikkan sebagai sosok yang menjadi panutan bagi anak tidak terkecuali berdampak bagi kemandirian anak. 
Dalam sebuah studi terhadap ayah dari 1.700 anak-anak berusia 12 tahun keatas, ditemukan bahwa ayah meluangkan waktu lebih banyak untuk anak-anak dibandingkan diawal tahun 1990-an, namun masih lebih sedikit dibandingkan ibu. Meskipun ada beberapa ayah yang memiliki komitmen luar biasa sebagai orang tua, sebagian ayah lain masih merasa asing terhadap remajanya meskipun mereka tinggal dirumah yang sama (Larson \& yeung dalam Dagun, 2002).

Interaksi dengan ayah yang mengasihi, mudah berkomunikasi dan dapat diandalkan, yang dapat memberikan kepercayaan dan keyakinan kepada anak-anaknya, sangat mendukung perkembangan sosial remaja (Jones, 2006). Dalam sebuah pendidikan, Frank Fustenberg \& Kathlen Haris (1992) medokumentasikan pengasuh ayah dapat mengatasi kesulitan anak ketika menghadapi situasi hidupnya (dalam Slameto, 2003)

Data yang didapatkan oleh National Parent Teacher Asosiation (Slameto, 2003) yang mendasarkan hasil penelitihan selama 30 tahun terakhir, menyimpulkan manfaat peran ayah bagi anak adalah makin baiknya tumbuh kembang anak secara fisik, sosioemosional, keterampilan kognitif, pengetahuan dan bagaimana anak belajar, dan anak mengikuti kegiatan baik intra maupun extrakulikuler, dengan itu anak akan terhindar dari keterlibatannya dalam kenakalan remaja seperti tawuran, kriminalitas, dan hal menyimpang lainnya.

Teori hard (dalam Nailul,2015) membagi peranan ayah dalam pengasuhan dalam delapan aspek: Economic Provider (Penyedia ekonomi).Memenuhi kebutuhan financial anak seperti perlengkapan sekolah anak dan lain-lain; Friend and playmate (Sebagai teman). Ayah dapat bergurau humor yang sehat, dapat menjalin hubungan baik sehingga problem, kesulitan dapat diatasi dan tidak mengganggu perkembangannya; Care giver (Pemberi perhatian dan kasih sayang). Ayah memberikan perhatian penuh sehingga anak merasa nyaman dan penuh kehangatan; Teacher and role model (Pendidik dan teladan). Ayah bertanggung jawab mengajari tentang apa saja yang diperlukan anak untuk kehidupannya melalui teladan yang baik sehingga berpengaruh positif; Monitor disciplinarian (Pemerhati disiplin). Ayah memonitor atau mengawasi perilaku anak begitu ada tanda-tanda awal penyimpangan bisa segera terdeteksi sehingga disiplin perilaku anak bisa segera ditegakkan; Protector (Pelindung). Ayah mengontrol lingkungan anak sehingga anak terbebas dari kesulitan dan resiko bahaya selama ayah tidak ada bersama anak; Advocate (Konsultan dan penasehat). Ayah membantu, mendampingi dan membela anak jika ada kesulitan atau masalah dengan demikian anak merasa aman, tidak sendiri dan ada tempat berkonsultasi; Resource (Sumber daya sosial dan akademik). Dengan berbagai cara dan bentuk ayah dapat mendukung keberhasilan anak.

Dukungan sosial adalah kesenangan yang dirasakan, penghargaan akan kepedulian atau bantuan yang diperoleh individu dari orang lain, dimana orang lain disini dapat diartikan sebagai perorangan atau kelompok. Hal tersebut menunjukkan bahwa segala sesuatu yang ada dilingkungan menjadi dukungan sosial atau tidak tergantung pada 
sejauh mana individu merasakan hal tersebut sebagai dukungan sosial (Sarafino dalam Smet, 2009).

Dukungan sosial merupakan suatu keadaan yang bermanfaat bagi individu perorangan maupun kelompok yang diperoleh dari orang lain yang meliputi informasi atau nasehat verbal atau non verbal, bantuan nyata (instrumental), perhatian, emosional dan pemberian nilai secara positif (penghargaan) terhadap individu tersebut sehingga mempunyai efek manfaat secara emosional bagi pihak penerima (Gottlieb dalam Smet, 2009).

\section{METODE PENELITIAN}

Dalam sebuah penelitian yang paling penting adalah metode yang digunakan dalam sebuah penilitian. Adapun metode yang digunakan dalam penelitian ini adalah pendekatan kuantitatif.

Adapun tempat penelitian ini adalah di Klinik Pemulihan Adiksi Medan Plus yang memiliki tiga tempat rehabilitasi yaitu jalan Jamin ginting pasar VII nomor 45 Padang bulan dijalan Laucih Padang Bulan dan di jalan Jend,Sudirman lorong murni kec. Stabat. Penelitian dilaksanakan pada tanggal 9 -11 Mei 2017.

Variabel penelitian dapat dibedakan menurut kedudukan dan jenisnya, yaitu variabel terikat dan variabel bebas. Adapun variabel dalam penelitian ini adalah: 1 . Variabel bebas yaitu variabel yang mempengaruhi variabel terikat atau dengan kata lain variabel yang variasinya mempengaruhi variabel lain (Azwar, 2003). Variabel bebas ini, meliputi: a. Peran Ayah yang dinyatakan dalam X1, b. Dukungan Sosial Teman Sebaya, yang dinyatakan dalam X2; 2 . Variabel terikat yaitu variabel penelitian yang diukur untuk mengetahui besarnya efek atau pengaruh variabel lain (Azwar, 2003). Dalam penelitian ini yang menjadi variabel terikat adalah determinasi diri, yang dinyatakan dalam Y.

Populasi yang dipakai dalam suatu penelitian adalah salah satu faktor penting yang harus diperhatikan, populasi adalah kumpulan dari individu dengan kualitas dan ciri-ciri yang telah ditetapkan. Populasi merupakan kumpulan atau keseluruhan subjek penelitian (Hadi, 2002). Populasi dalam penelitian ini adalah jumlah keseluruhan pecandu yang sedang rehabilitasi di klinik pemulihan adiksi medan plus sebanyak 178 orang.

Sampel adalah sebagian dari populasi yang diambil untuk mendapatkan gambaran dari seluruh populasi. Untuk menentukan besar kecilnya ukuran sampel harus mempertimbangkan berbagai faktor termasuk besarnya tenaga, waktu dan dana. Sebagian peneliti mengatakan bahwa ukuran sampel tidak boleh kurang dari 5\% dari ukuran populasi, tetapi sebagian lagi mengatakan tidak kurang dari 10\% (Lubis, 2010).

Dalam menggunakan teknik sampel ini ada syarat-syarat yang harus dipenuhi yaitu: a. Pengambilan sampel harus didasarkan atas ciri-ciri, sifat-sifat atau karakteristik tertentu, yang merupakan ciri-ciri pokok populasi; b. Subjek yang diambil sebagai sampel benar-benar merupakan subjek yang paling banyak mengandung ciri-ciri yang terdapat pada populasi; c. Penentuan karakteristik populasi dilakukan dengan cermat didalam studi pendahuluan. 
Dalam penelitian ini metode pengambilan sampel yang digunakan adalah purposive sampling. Menurut Lubis (2010) purposive sampling atau sampel secara sengaja adalah metode penarikan sampel dari populasi dengan tidak mempertimbangkan peluang (non probability sampling), dimana sampel secara sengaja dilakukan dengan memilih sampel yang sesuai dengan kriteria tertentu dan mengabaikan yang tidak sesuai dengan kriteria tersebut. Adapun kriteria sampel yang digunakan dalam penelitian ini adalah remaja berusia 15-20 tahun dan atau masih menjalani pendidikan dan remaja yang tinggal bersama orangtua. Adapun subjek dalam penelitian ini adalah remaja pecandu narkoba di Klinik Adiksi Medan Plus yang sesuai dengan kriteria penelitian adalah berjumlah 54 orang.

Metode yang digunakan dalam penelitian ini adalah metode korelasional yang terdiri dari tiga variabel yaitu variabel X1 (Peran Ayah), variabel X2 (dukungan sosial teman sebaya) dan variabel Y (Determinasi Diri). Korelasi merupakan angka yang menunjukkan arah kuatnya hubungan antar dua variabel atau lebih.

Angket dalam penelitian ini menggunakan skala likert, yaitu responden diminta memilih salah satu dari empat alternatif jawaban. Adapun keempat alternatif jawaban tersebut adalah ; sangat setuju (SS), setuju (S), tidak setuju (TS) dan sangat tidak setuju (STS). Penilaian yang diberikan untuk setiap butir pernyataan favourable yaitu; nilai 4 untuk jawaban sangat setuju (SS), nilai 3 untuk jawaban setuju (S), nilai 2 untuk jawaban tidak setuju (TS) dan nilai 1 untuk jawaban sangat tidak setuju (STS). Sebaliknya penilaian yang diberikan untuk setiap butir pernyataan unfavourable yaitu; nilai 1 untuk jawaban sangat setuju (SS), nilai 2 untuk jawaban setuju (S), nilai 3 untuk jawaban tidak setuju (TS) dan nilai 4 untuk jawaban sangat tidak setuju (STS) (Suryabrata,1998).

Data yang diperoleh dari subjek melalui skala ukur di transformasi ke dalam angka-angka menjadi data kuantitatif, sehingga data tersebut dapat dianalisis dengan pendekatan statistik. Ada dua hal yang dilakukan dalam analisis data kuantitatif dalam penelitian ini, yaitu: 1). Analisis data dalam penelitian ini adalah uji prasyarat yang meliputi uji normalitas sebaran dan uji linieritas hubungan, dan 2). Uji hipotesis penelitian dengan menggunakan regresi ganda pada hipotesis ketiga dan regresi sederhana pada hipotesis satu dan dua.

Sebelum sampai pada pengolahan data, data yang akan diolah nanti haruslah berasal dari alat ukur yang mencerminkan fenomena apa yang diukur. Untuk itu perlu dilakukan analisis butir (Validitas dan Reliabilitas).

Validitas adalah suatu ukuran yang menunjukkan tingkat - tingkat validitas atau kesahihan suatu instrument (hadi, 2002). Sebuah instrumen dapat dikatakan valid apabila dapat mengungkap data dari variabel yang diteliti atau dengan kata lain mampu mengukur apa yang hendak diukur. Sebuah alat ukur dapat dinyatakan mempunyai validitas yang tinggi apabila alat ukur tersebut menjalankan peran ukurnya atau memberikan hasil ukur yang sesuai dengan maksud dikenakannya alat ukur tersebut. Uji validitas dilakukan untuk mengetahui sejauh mana ketepatan dan kecermatan skala pengukuran dalam melakukan peran ukurnya. Suatu item diterima dan dianggap memuaskan apabila koefisien korelasi (rxy) melebihi = 0,30 (Azwar, 2003). Teknik yang 
digunakan untuk menguji validitas alat ukur (angket) adalah teknik korelasi Product Moment dari Karl Pearson.

Reliabilitas merujuk pada konsistensi skor yang dicapai oleh individu yang sama ketika mereka di uji ulang dengan tes yang sama pada kesempatan yang berbeda. Reliabel artinya dapat dipercaya, jadi dapat diandalkan.

Apabila instrumentnya sudah baik dan dapat dipercaya (reliable) maka beberapa kali di uji cobakan pada waktu yang berbeda dan pada subjek yang sama maka akan tetap sama hasilnya.

\section{HASIL DAN PEMBAHASAN}

Uji normalitas untuk melihat penyimpangan frekuensi observasi yangditeliti dari frekuensi teoritik. Uji asumsi normalitas menggunakan teknik statistik non parametrik one sample Kolmogrov-Smirnov. Kaidah yang digunakan adalah jika p > 0.05 maka sebarannya normal, sebaliknya jika $\mathrm{p}<0.05$ maka sebarannya tidak normal (dalam Hadi, 2000).

Tabel 1

Hasil Uji Normalitas

\begin{tabular}{cccc}
\hline Variabel & $\begin{array}{c}\text { Kolmogorof- } \\
\text { Smirnof Z }\end{array}$ & $\mathrm{P}$ & Keterangan \\
\hline $\begin{array}{c}\text { Determinasi } \\
\text { Diri }\end{array}$ & 0,066 & 0,200 & Normal \\
\hline
\end{tabular}

Tabel 1 dapat ditafsirkan sebagai berikut: hasil uji asumsi normalitas sebaran terhadap variabel determinasi diri menghasilkan nilai $Z=0,066$ dan $p=0.200$ ( $p>0.05)$. Hasil uji berdasarkan kaidah menunjukkan sebaran data variabel determinasi diri adalah normal.

Uji asumsi linieritas dilakukan untuk mengetahui linieritas hubungan antara variabel bebas dengan variabel terikat. Uji linieritas dapat pula untuk mengetahui taraf penyimpangan dari linieritas hubungan tersebut. Adapun kaidah yang digunakan dalam uji linieritas hubungan adalah bila nilai linierity $\mathrm{p}<0.05$ maka hubungan dinyatakan linier, atau bila nilai deviant for linerity $\mathrm{p}>0.05$ maka hubungan dinyatakan linier.

Tabel 2

Hasil Uji Linieritas Hubungan

\begin{tabular}{|c|c|c|c|}
\hline Variabel & $\mathrm{F}$ & $\mathrm{P}$ & Keterangan \\
\hline $\begin{array}{c}\text { Peran ayah - } \\
\text { Determinasi } \\
\text { diri }\end{array}$ & 19,825 & 0,000 & Linier \\
\hline $\begin{array}{c}\text { Dukungan } \\
\text { sosial - } \\
\text { Determinasi } \\
\text { diri }\end{array}$ & 9,246 & 0,005 & Linier \\
\hline
\end{tabular}

Pada tabel 2 di atas didapatkan hasil bahwa: 1) Hasil uji asumsi linieritas antara variabel peran ayah dengan determinasi diri mempunyai nilai linearity $F=19,825$ dan $p$ $=0.000$ yang < 0.05 yang berarti hubungannya dinyatakan linier; 2) Hasil uji linieritas pada variabel dukungan sosial dengan determinasi diri diperoleh nilai linearity $F=9,246$ 
dan $p=0,005$ yang $<0.05$. Hal ini menunjukkan bahwa hubungan kedua variabel tersebut linier.

Ada tiga hipotesis yang diajukan dalam penelitian ini; (1) ada hubungan antara peran ayah dengan determinasi diri remaja; (2) ada hubungan antara dukungan sosial dengan determinasi remaja; (3) ada hubungan antara peran ayah dan dukungan sosial dengan determinasi diri remaja.

Ketiga hipotesis tersebut ternyata terbukti semua dalam penelitian ini. Penjelasan selengkapnya adalah sebagai berikut: (1) ada hubungan positif antara peran ayah dengan determinasi diri remaja, yang ditunjukkan oleh koefisien rx1y =0,543 dan $p<0,01$; (2) ada hubungan positif antara dukungan sosial dengan determinasi diri yang ditunjukkan oleh koefisien rx2y = 0,384 dan $p<0,01$; untuk kedua hipotesis di atas digunakan teknik analisis product moment; (3) ada hubungan positif antara peran ayah dan dukungan sosial dengan determinasi diri yang ditunjukkan oleh koefisien $\mathrm{F}=11,071$ dan $\mathrm{R}=0,550$ sedangkan $\mathrm{R} 2=0,303$ dengan $\mathrm{p}<0,01$.

Hipotesis ke tiga dalam penelitian adalah untuk mengetahui daya prediksi peran ayah dan dukungan sosial terhadap munculnya determinasi diri remaja, analisis yang digunakan adalah analisis regresi berganda. Berdasarkan hasil pengujian product moment dan regresi model penuh atas variabel- variabel bebas peran ayah dan dukungan sosial dengan determinasi diri didapatkan hasil sebagai berikut:

Tabel 3

Ringkasan Hasil Analisis Data

\begin{tabular}{cccc}
\hline Variabel & $\mathrm{F}$ & $\mathrm{R}$ & $\mathrm{r} 2 / \mathrm{R} 2$ \\
\hline $\mathrm{X} 1-\mathrm{Y}$ & - & 0,543 & 0,295 \\
\hline $\mathrm{X} 2-\mathrm{Y}$ & - & 0,384 & 0,147 \\
\hline $\mathrm{X} 1 \mathrm{X} 2-\mathrm{Y}$ & 11,071 & 0,550 & 0,303 \\
\hline Variabel & $\mathrm{F}$ & $\mathrm{R}$ & $\mathrm{r} 2 / \mathrm{R} 2$ \\
\hline
\end{tabular}

Berdasarkan data tabel 3 menunjukkan bahwa peran ayah memiliki daya prediksi terhadap munculnya determinasi diri yang ditunjukkan oleh koefisien $r^{2}$ sebesar 0,295 yang artinya ada 29,5 \% peran ayah mempengaruhi determinasi diri, sedangkan dukungan sosial memiliki daya prediksi terhadap munculnya determinasi diri sebesar $14,7 \%$; secara bersama-sama peran ayah dan dukungan sosial memiliki daya prediksi terhadap munculnya determinasi diri sebesar 30,3 \%. Hal tersebut memberi makna bahwa secara bersama kedua variabel tersebut, yaitu peran ayah dan dukungan sosial menentukan munculnya determinasi diri sebesar 30,3\%.

Pada variabel peran ayah, jumlah butir yang valid sebanyak 64 butir dengan format skala linkert dengan 4 pilihan jawaban, maka diperoleh mean hipotetik $\{(67 \times 1)+$ $(67 x 4)\} / 2=167,5$

Pada variabel dukungan sosial teman sebaya, jumlah butir yang valid sebanyak 25 butir dengan format skala likert dengan 4 pilihan jawaban, maka diperoleh mean hipotetik $\{(25 \times 1)+(25 \times 4)\} / 2=62,5$. 
Pada variabel determinasi diri, jumlah butir yang valid sebanyak 25 butir dengan format skala likert dengan 4 pilihan jawaban, maka diperoleh mean hipotetik $\{(25 \mathrm{x} 1)+$ $(25 \times 4) / 2=62,5$.

Berdasarkan analisis data, seperti yang terlihat dari uji normalitas sebaran diketahui bahwa mean empirik variabel peran ayah adalah 187,48 dan variabel dukungan sosial teman sebaya memiliki mean empirik sebesar 64,68 serta variabel determinasi diri memiliki mean empirik sebesar 67,85.

Tabel 4

Hasil Perhitungan Nilai Rata-Rata Hipotetik Dan Nilai Rata-Rata Empirik

\begin{tabular}{ccccc}
\hline Variabel & \multicolumn{3}{c}{ Nilai Rata- Rata } & Keterangan \\
\cline { 2 - 5 } & Hipotetik & Empirik & SD & \\
\hline Peran ayah & 167,5 & 187,48 & 25,79 & Sedang \\
\hline $\begin{array}{c}\text { Dukungan sosial } \\
\text { teman sebaya }\end{array}$ & 62,5 & 64,68 & 9,912 & Sedang \\
\hline Determinasi diri & 62,5 & 67,85 & 6,893 & Sedang \\
\hline
\end{tabular}

Berdasarkan perbandingan kedua nilai rata-rata diatas (mean hipotetik dan mean empirik), maka dapat dinyatakan bahwa subjek penelitian ini memiliki peran ayah yang tergolong sedang dan memiliki dukungan sosial teman sebaya yang tergolong sedang dan determinasi diri yang diperoleh tergolong sedang. Dengan demikian dapat dinyatakan bahwa hipotesis yang diajukan dalam penelitian ini adalah diterima.

Hasil yang diperoleh dari uji hipotesis pertama menggunakan teknik analisis product moment diperoleh nilai korelasi $\mathrm{r}_{\mathrm{x} 1 \mathrm{y}}=0,543$ dan $\mathrm{p}<0,01$, hal ini menunjukkan bahwa hipotesis pertama penelitian diterima yaitu ada hubungan positif antara peran ayah dengan determinasi diri pada remaja pecandu narkoba di Klinik Pemulihan Adiksi Medan Plus. Semakin tinggi peran ayah maka semakin tinggi determinasi diri pada remaja pecandu narkoba di Klinik Pemulihan Adiksi Medan Plus, sebaliknya semakin rendah peran ayah maka semakin rendah pula determinasi diri pada remaja pecandu narkoba di Klinik Pemulihan Adiksi Medan Plus.

Videon (dalam Nailul, 2015) mengatakan bahwa keterlibatan ayah dalam kehidupan remaja akan mempengaruhi mereka dalam hubungan dengan sebaya dan prestasi sekolah, serta membantu remaja dalam mengembangkan pengendalian dan penyesuaian diri dengan lingkungan. Remaja yang hidup tanpa Ayah lebih cenderung memilih teman yang menyimpang, mengalami kesulitan bergaul dengan remaja lain, mengalami masalah dengan teman sebaya dan hubungan dengan teman sebaya menjadi semakin agresif, sampai terlibat dalam perilaku kriminal atau melakukan kejahatan, memiliki, menggunakan, mendistribusikan alkohol atau obat-obatan dan terlibat seks bebas. Oleh karena itu peran ayah sangat membantu terbentuknya determinasi yang tinggi pada diri seorang remaja.

Penelitian yang dilakukan Misched (dalam Dagun, 2002) juga menunjukkan hasil ternyata karena ketidakhadiran ayah remaja menjadi lamban menanggapi kehendak, keinginan dan kebutuhannya. 
Penelitian yang dilakukan oleh Nailul (2015) "Pengaruh Peran Ayah dengan Determinasi Diri" mengupas kajian-kajian mengenai peran ayah dalam perkembangan remaja. Peneliti membahas bagaimana pengaruh peran ayah dalam membangun determinasi diri remaja mengingat ayah adalah agen sosial yang paling dekat dengan anak selain ibu. Pada penelitian ini menunjukan hasil peran ayah dalam pengasuhan memberikan pengaruh positif terhadap determinasi diri remaja.

Hasil uji hipotesis kedua antara dukungan sosial teman sebaya dengan determinasi diri yang ditunjukkan oleh koefisien $r_{x 2 y}=0,384$ dan $p<0,01$, hal ini menunjukkan bahwa hipotesis kedua penelitian diterima yaitu ada hubungan positif antara dukungan sosial teman sebaya dengan determinasi diri pada remaja pecandu narkoba di Klinik Pemulihan Adiksi Medan Plus. Semakin tinggi dukungan sosial teman sebaya maka semakin tinggi pula determinasi diri berprestasi pada remaja pecandu narkoba di Klinik Pemulihan Adiksi Medan Plus, sebaliknya pula semakin rendah dukungan sosial teman sebaya maka semakin rendah pula determinasi diri pada remaja pecandu narkoba di Klinik Pemulihan Adiksi Medan Plus.

Hasil penelitian ini sejalalan dengan pendapat Santrock (2007) yang mengemukakan bahwa salah satu fungsi kelompok teman sebaya yang paling penting adalah menyediakan suatu sumber informasi dan perbandingan tentang dunia luar keluarga. Dari kelompok teman sebaya, remaja menerima umpan balik mengenai kemampuan mereka. Remaja belajar tentang apakah yang mereka lakukan lebih baik, sama baiknya atau bahkan lebih buruk dari apa yang dilakukan remaja lainnya. Dukungan sosial teman sebaya yang tinggi akan berdampak baik terhadap terbentuknya determinasi diri yang tinggi pada remaja. Seorang remaja yang memiliki determinasi diri yang tinggi mempunyai kemampuan bertindak atas dirinya dalam membuat pilihan dan menentukan cara-cara mememenuhi kebetuhannya sehingga remaja lebih mampu untuk mengontrol dirinya sendiri.

Hasil yang diperoleh dari uji hipotesis ketiga menggunakan teknik analisis regresi ganda diperoleh koefisien $F=11,071$ dan $R=0,550$ sedangkan $R^{2}=0,303$ dengan $p<$ 0,01, hal ini menunjukkan bahwa ada hubungan positif antara peran ayah dan dukungan sosial dengan determinasi diri remaja di Klinik Pemulihan Adiksi Medan Plus. Hasil penelitian sejalan dengan Nailul (2015), peran ayah memiliki pengaruh penting bagi determinasi diri remaja. Peran ayah memiliki daya prediksi terhadap munculnya determinasi diri yang ditunjukkan oleh koefisien $r^{2}$ sebesar 0,295 yang artinya ada 29,5 $\%$ peran ayah mempengaruhi determinasi diri, sedangkan dukungan sosial memiliki daya prediksi terhadap munculnya determinasi diri sebesar 14,7 \%; secara bersamasama peran ayah dan dukungan sosial memiliki daya prediksi terhadap munculnya determinasi diri sebesar 30,3 \%. Hal tersebut memberi makna bahwa secara bersama kedua variabel tersebut, yaitu peran ayah dan dukungan sosial menentukan munculnya determinasi diri sebesar 30,3\%.

Berdasarkan hipotesis diatas maka dapat disimpulkan bahwa determinasi diri akan terbentuk pada remaja dalam berkembang menjadi mahluk sosial dan yang secara regulasi juga mempengaruhi diri mereka sendiri. Dan orang tua terkhususnya ayah 
sangat mempengaruhi dalam membentuk kepribadian diri dari individu remaja tersebut. Terkait pada peran individu remaja tersebut dalam bersosial. Karena lingkungan khususnya teman sebaya sangat berpengaruh besar terhadap pembentukan pola pikir dan bertindak dari seorang remaja tersebut.

\section{SIMPULAN}

Berdasarkan hasil analisis statistik yang telah dilakukan dalam penelitian ini, maka dapat ditemukan beberapa kesimpulan, yaitu: 1 . Ada hubungan positif antara peran ayah dengan determinasi diri remaja di Klinik Pemulihan Adiksi Medan Plus yang ditunjukkan oleh rxy $=0,543$ dengan $\mathrm{p}<0,01$. Artinya semakin besar peran ayah yang dirasakan remaja akan semakin meningkatkan determinasi dirinya; 2. Ada hubungan positif antara dukungan sosial dengan determinasi diri remaja di Klinik Pemulihan Adiksi Medan Plus yang ditunjukkan oleh koefisien $r x y=0,384$ dengan $\mathrm{p}<0,01$. Artinya semakin banyak dukungan sosial akan semakin meningkatkan determinasi dirinya; 3. Ada hubungan positif antara peran ayah dan dukungan sosial dengan determinasi diri remaja di Klinik Pemulihan Adiksi Medan Plus yang ditunjukkan oleh koefisien F = 11,071; R = 0,$550 ; \mathrm{R} 2=0,303$ dengan $\mathrm{p}<0,01$.

\section{DAFTAR PUSTAKA}

Amie, R. (2008). Hubungan dukungan sosial teman sebaya dengan identitas diri pada remaja di SMA Pusaka I Jakarta. Jurnal Psikologi, Universitas Gunadarma, Vol. 3, Issue date : November 2008

Azwar, S. (2003). Reliabelitas dan Validitas Alat Ukur. Yogyakarta. Penerbit Pustaka Belajar Dagun. (2002). Psikologi Keluarga. Jakarta. Penerbit Rineka Cipta

Fiest J \& Fiest Gregory J. (2008).Theory Of Psychology. Edisi Keenam. Yogyakarta. Penerbit Pustaka Belajar Hadi,S. (2002). Metodology Research II.Cetakan ke-27. Jakarta. Penerbit Andi Offset

Hamdani, R., Lahmuddin L., Aziz, A., (2015), Hubungan antara Dukungan Sosial dan Kecerdasan Emosional dengan Self-Regulated Learning Siswa. Analitika: 7 (2): 105-117

Mahaldi, H. (2015). Tak ada anak hebat tanpa ayah luar biasa. Jakarta. Penerbit Kultum Media

Nailul Muna, L. (2015). Pengaruh peran ayah terhadap determinasi diri remaja. Jurnal Psikoislamika Universitas Islam Negeri Malang, 12 Vol.1. ISSN. 1829-5703

Nainggolan, W.S.. Chandra, A., \& Sembiring, S.A. (2017). Hubungan Dukungan Sosial dengan Harga Diri pada Mantan Pengguna Narkoba, Jurnal Diversita, 3 (2): 94-100

Nura, E. (2011). Hubungan dukungan teman sebaya dan religiusitas dengan perilaku seks pranikah pada mahasiswa. Jurnal Psikologi. Universitas Islam Bandung.ISSN.2059-3590.Vol. 2.No. 1. 2011

Rianti, A. A. (2013). Cara Rasulullah SAW mendidik anak. Jakarta. PT. Elex Media Komputindo

Santrock, J. W. (2007). Perkembangan anak. Jilid II. Jakarta. Penerbit Erlangga

Schunck. (2012). Motivasi dan pendidikan. Edisi Ketiga. Penerbit Indeks

Siregar, N. (2018). Kualitas Hidup Wanita Menopause Ditinjau dari Dukungan Sosial di Kelurahan Sempakata Padang Bulan Medan. JURNAL DIVERSITA, doi:https://doi.org/10.31289/diversita.v4i1.1566

Slameto. (2014). Peranan ayah dalam mendidik anak dan hubungan dengan prestasi belajarnya. Jurnal sector Pendidikan. nomor.2 Vol.10 Issue date: Desember, 2014

Smet, B. (2009). Psikologi Kesehatan. Jakarta. PT. Grasindo

Suryasubrata. (1998). Pengembangan Alat Ukur Psikologi. Yogyakarta. Penerbit andi offset.

Tarigan, M. (2018). Hubungan Dukungan Sosial dengan Subjective Well-Being pada Remaja yang Memiliki Orangtua Tunggal. JURNAL DIVERSITA, 4(1), 1-8. doi:https://doi.org/10.31289/diversita.v4i1.1565

Zuraida, Kaiman T, Sri S, (2015), Hubungan Kecerdasan Emosional dan Dukungan Sosial Keluarga dengan Burnout, Analitika: 7 (2): 141-149. 